\title{
The Impact of Agricultural Market Information System in Bosnia \& Herzegovina on Market Integration: Assymetric Information and Market Performance
}

\author{
Adisa Omerbegovic Arapovic \\ Sarajevo School of Science and Technology, Bosnia and Herzegovina

\section{Zana Karkin} \\ Sarajevo School of Science and Technology, Bosnia and Herzegovina
}

\section{INTRODUCTION}

When identical commodities are being exchanged between two or more markets, the prices of those commodities should be equal according to the law of one price, with the only difference in the transport cost between those markets. Therefore, in the perfectly integrated economy, local demand has no impact onto the formation of the market price, and once changes in local demand occur, the prices are being equalized in the national market through efficient allocation of resources (Pareto efficiency). Quantity supplied is being adjusted by shifting goods towards the markets with higher demand. This represents "the first fundamental theorem of welfare economics", which is confirmation of Adam Smith's "invisible hand". The concept is further expanded first by Stigler, explaining the relevance of market information for the purpose of increasing market efficiency. When there is lacking significant market information, agents in the market cannot engage in optimal arbitrage and the price dispersion is present, so therefore markets are not efficient (Stigler, 1961). We put this theory into perspective of the particular setting in $\mathrm{B} \& \mathrm{H}$. We analysethe extent of agro-food market integration in B\&H by studying price differentials between different market locations to answer whether the introduction of ICT service improved market efficiency, thereby potentially revealing that actors in the market did not actually have access to relevant price information.

The setting of the study is $\mathrm{B} \& \mathrm{H}$ post-war recovery, which is marked by the process of economic transition introducing market reforms to former centrally-planned economy. As part of the process of transition from a centrally-planned economy, $\mathrm{B} \& \mathrm{H}$ producers that were previously strictly guided by the system are left to cope 
with the market uncertainty on their own. The market failures have been identified to exist in the form of fragmented supply chains which reduces the competitiveness of the local producers (World Bank, 2010) which hampers the development of the sector, which is quite important sector for employment given that $20.6 \%$ of all employed in 2010 are in this sector. In this context ICT can play a significant role in curing some of the problems of agriculture product markets, particularly market segmentation and asymmetric information. Agro-food market information system implemented by Agriculture e-BIZ Center- AgroLink in the beginning of 2010 was intended to provide information about the price of agricultural items sold at the agro-food markets in $\mathrm{B} \& \mathrm{H}$ with an intention to improve functioning of the agrofood market. The data obtained from the AgroLink service pre and post introduction of ICT become the basis for our research on impact of ICT on market integration.

Theoretical basis is found in Jensen (2007), who has shown that the introduction of mobile telephony had significant results towards improving market performance of fish market in India by proving that excess supply has been managed more efficiently with information on different market locations provided. The methodlogy for measuring degree of market in integration is found in Gluschenko (2003, and 2010) whotests the Law of One Price while controlling for transportation costs, to test the role of local demand in determination of prices in local markets as in perfectly integrated markets Law of One Price holds given the difference in transportation costs and local demand has no role in price determination. Along that logic more integrated markets as ones with the lower impact of the local demand in price formation. This approach can be used to analyse a degree of market integration as it was used to study a feasible degree of market integration in Russia during the transformation years bycomparing parameter on local demand with those of developed mature markets of similar structure. Therefore, we do not have to observe zero parameter for impact of local demand as this may not be feasible given the fact that more mature markets do not exhibit perfect integration in this sense. Following this methodology and having our intention to test whether market performance has improved post SMS service, we test the size of the parameter of local market demand on price determination pre and post ICT service. Statistically significant difference in pre and post parameter of local demand influence on price formation could therefore indicate that information provided via SMS service has improved the market efficiency.

The paper is organized as follows: Section 2 presents methodology used to test degree of market integration, Section 3 presents data for price differentials, income and distance variables. We present econometric results of analysis in Section 4 which suggests that ICT service has had an impact on degree of market integration. 
Section 5 presents the concluding remarks on whether our results warrant further use of ICT for policy makers in curing the problem of asymmetric information and market performance.

\section{METHODOLOGY}

Following the methodological justification of Gluschenko(2003, and 2010),we state that since the market is composed of sub-markets, $\mathrm{p}_{\mathrm{r}}$ represents a price of a good in location $r$, it is considered that the income per capita $\left(i_{r}\right)$ is the only determinant of demand, $\mathrm{q}_{\mathrm{r}}=\mathrm{D}\left(\mathrm{p}_{\mathrm{r}}, \mathrm{i}_{\mathrm{r}}\right)$ represents the demand function, and $\mathrm{q}_{\mathrm{r}}=\mathrm{S}\left(\mathrm{p}_{\mathrm{r}}\right)$ the supply function. All variables are represented as logarithms $\left(\operatorname{Pr}=\ln p_{r}\right)$, and denoted by uppercase letters for the distinction purposes. Considering that the data on quantities demanded is mostly unavailable, it is more convenient to provide a relationship between prices and incomes, therefore the equilibrium market condition is the following:

$$
\begin{gathered}
\mathrm{D}\left(P_{r}, I_{r}\right)-\mathrm{S}\left(P_{r}\right)=0 \\
\text { and } \\
P_{r}=\kappa+\beta I_{r}
\end{gathered}
$$

In a perfectly integrated market $\beta=0$, in order for the law of one price to hold.

If the location pair is taken, including location $r$ and $s$, subtracting data from one market, with data from another, the following is obtained:

$$
\begin{gathered}
P_{r s}=P_{r}-P_{s}=\ln \left(p_{r} / p_{s}\right) \\
\text { and } \\
P_{r s}=\beta I_{r s}=\ln \left(i_{r} / i_{s}\right)
\end{gathered}
$$

Under the law of one price, $P_{r s}$, representing a price differential, should be equal to 0 , therefore $\beta$ should be equal to 0 .

The relationship under equation (2) is taken by Gluschenko as a cross-sectional test for market segmentation, where a higher value of $\beta$ represents weaker integration, indicating that markets are not perfectly integrated.

In the context of our impact assessment, we test the hypothesis that introduction of ICT service in agro-food market in $\mathrm{B} \& \mathrm{H}$ has increased the level of market integration. If the mobile service improved integration of markets, the coefficient on income is expected to be insignificant in the post-ICT introduction data set or significantly reduced. In addition, negative slope of coefficient on income $(\beta)$ would indicate that local demand does not have a role in price determination as 
negative relationship between income and price differential indicates that positive income differential in favour of one market location, indicating higher local demand, is associated with lower price at that location. This is opposite to theoretically postulated relationship, which enables us to conclude that negative coefficient on income indicates that local demand has no role in price determination.

The empirical form of the equation which is used to test the hypothesis is adjusted in order to control for the transportation costs. They represent a relevant factor for price determination when distances are larger, and they are represented as loglinear function of distance, $T_{r s}=\alpha+\gamma L_{r s}$. When error term is added, the following equation is derived as an econometric version of the equation (2):

$$
P_{r s i}=\alpha+\beta I_{r s i}+\gamma L_{r s i}+\varepsilon_{r s i}
$$

Where $r s=1 . . n$ and $i=1$..t. Where $r$ refers to differential between location $r$ and location s, so that $n$ location pair differentials $r$ are analysed over the time period ${ }_{i}$ which has $t$ number of daily price observations.

$\mathrm{N}$ being number of markets/locations, total number of locations pairs is $\mathrm{n}=\mathrm{N} *(\mathrm{~N}$ 1) / 2, to avoid duplication of pairs, we included only one direction in analysis of $P_{r s}$ (e.g. from s to $\mathrm{r}$, or from $\mathrm{r}$ to $\mathrm{s}$, but not both). We pool data for these location pairs in order to run econometrics tests on Equation 3 using a time series data for $n$ location pairs on daily price differentials for $t$ number of daily price observations.

Considering the aim of this research is to analyse the difference in market integration before and after the introduction of the market information system, the dataset is divided onto two samples, to reflect the period before and after the introduction of the service.

\section{DATA COLLECTION AND DESCRIPTION}

Data analysed represents daily prices of eight agro-food products covering the period from April 2010 to October 2011, collected by reporters of Agriculture eBIZ Center - AgroLink. Since the service was launched in April 2011, April $15^{\text {th }}$ 2011 is considered to be the date that divides two periods, the period before and the period after the introduction of the service.

AgroLink provides daily information on prices of 60 agro-food products, but taking into account that this is a pilot study, goods that are typically produced in B\&H by larger number of farmers are selected. Another aspect that was relevant when selecting goods was quality of a dataset, so goods selected also represent datasets that had fewer missing values. Eight goods were selected that are regularly produced in $\mathrm{B} \& \mathrm{H}$, including: tomato, strawberry, apple, cucumber, potatoes spring, pepper, peach and garlic. 
Income variable was captured bythe average reported gross wage for the location in question so that income differentials between locations could be calculated.

Transportation costs were estimated by kilometre distances between locations.

Our data set is therefore pooled time series cross section data using 10 location pairs generated from 5 markets, namely Sarajevo, BanjaLuka, Capljina, Arizona and Bijeljina, over the period of $15^{\text {th }}$ April 2010 until October 2011.

\section{EMPIRICAL RESULTS}

Our data that enter equation (3) exhibit stationary so we estimate Equation (3) over two datasets, one denoting period before, and the other denoting period after the introduction of the market information system. As previously mentioned, variables in the analysis reflect location pair differentials, with 10 location pairs in total, considering that the data for 5 wholesale markets is made available. Analysis is done for each of the eight products separately, followed by the complete regression analysis of all the selected products together using pooled time series analysis cross section data for 10 location pairs. We run independently pooled panels as we take assumption of no unique attributes of location pair differentials within the measurement set, and no universal effects over time.

As explained, levels of $\beta$ denote levels of market integration. When observing the regression results for the dataset as a whole (see Table 1), $\beta$ is positive and highly statistically significant before the service was introduced indicating that law of one price does not hold for agro-food market in B\&H, as expected. Post-ICT introduction results indicate negative coefficient on income indicating no role of local demand on price differential, as higher local demand is associated with lower price, opposite to postulated theoretical relationship ${ }^{1}$. This reduction in price due to higher local demand supports the argument of greater market integration as higher local demand is met by changes in supply post ICT introduction as postulated by theory. (Pareto efficiency) When we observe $\beta$ for particular goods, the estimates differ. In the period before the introduction of the service all the estimates are statistically significant at 1 percent level, except for the pepper and tomato being significant at 5 percent, and peach being significant at 10 percent level. After the service has been introduced, apple, new potatoes, cucumber, and garlic have insignificant $\beta$ estimates, indicating that agro-food markets became integrated

\footnotetext{
${ }^{1}$ We have set the direction of location pairs in such a way that income differential between two locations is such that there is positive income differential between locations $r$ and $s$. Therefore, negative $\beta$ has no theoretical validity as positive income differential in favour of location $r$ is associated with negative price differential, or lower price at location $r$, so that local demand has no role in price determination as its expected effect would be to increase the price at location $r$.
} 
when it comes to these particular individual goods. For cases where $\beta$ remained significant variable it has observed negative relationship with price differential indicating that local demand has no role in setting of the price. This is only not case with strawberries where local demand seems to still have role in price determination after the ICT service was introduced as we observe reduction of $\beta$ estimate from 0.62 to 0.36 , while remaining statistically significant.

$\beta$ estimates reveal that the market integration improved after the introduction of the service, considering that for aggregated markets for all products as well as the majority of goods (except for those for which $\beta$ is insignificant after the introduction of the service), $\beta$ is negative in the period after the service is introduced as it was expected. The estimate for $\beta$ is only not negative for strawberry, though it dropped from 0,6215 to 0,3638 , signifying that there has been some increase in the level of market integration. This difference is in line with findings of Gluschenko (2010) where the results for different products varied significantly, which provided the evidence that sub-markets exhibit different degrees of integration. Due to this it is further suggested that it makes sense to use aggregated markets only as benchmarks for measuring the feasible degree of market integration. Degree of market integration for agriculture market as a whole when compared to the market for Russia as found in Gluschenko (2010) relating to potatoes as measured through the size of $\beta$ of 0.07 is at a lower level, suggesting that there is further room for improvement.

The empirical data confirms distance between markets as a relevant determinant of prices, both in the period pre and post introduction of the ICT service. This is shown in estimates for all products, as well as for most figures obtained for separate products. Coefficient for distance for the whole dataset is highly significant at 1 percent level for both pre and post periods included. Estimates of this parameter for all the goods in the period before ICT are also significant at 1 percent level, apart from the peach and garlic for which $\gamma$ is insignificant, meaning that existing price distortions between different locations of agro food market for peach and garlic are not explained by the distance, represented by the transportation costs in the period before introduction of the service. In the post ICT period, only $\gamma$ estimate for pepper is insignificant, spring potatoes and garlic being significant at 10 percent level, peach at 5 percent level, and other goods having $\gamma$ estimates significant at 1 percent level. Overall, the results give support for conducting the test on Law of One Price while taking into account the transportation costs.

Table 1 -Parameter $\beta$ estimates from regression analysis, which is defined in Equation (3). Results for individual goods and whole dataset with all products 
Adisa Omerbegovic Arapovic, Zana Karkin

\begin{tabular}{|c|c|c|c|c|c|c|c|c|}
\hline $\begin{array}{c}\text { ncome } \\
\beta\end{array}$ & \multicolumn{4}{|c|}{ Pre ICT } & \multicolumn{4}{c|}{ Post ICT } \\
\cline { 2 - 8 } & Estimate & $\begin{array}{c}\text { Standard } \\
\text { Error }\end{array}$ & Prob. & F -statistic & Estimate & $\begin{array}{c}\text { Standard } \\
\text { Error }\end{array}$ & Prob. & F -statistic \\
\hline Tomato & 0,0967 & 0,0396 & 0,0148 & $\begin{array}{c}71.88 \\
(0.0000)\end{array}$ & $-0,2689$ & 0,0961 & 0,0053 & $\begin{array}{c}20.08 \\
(0.0000)\end{array}$ \\
\hline $\begin{array}{c}\text { Straw } \\
\text { berries }\end{array}$ & 0,6215 & 0,1111 & 0,0000 & $\begin{array}{c}15.65 \\
(0.0000)\end{array}$ & 0,3638 & 0,0936 & 0,0001 & $\begin{array}{c}9.95 \\
(0.0000)\end{array}$ \\
\hline Apple & 0,2799 & 0,0406 & 0,0000 & $\begin{array}{c}53.33 \\
(0.0000)\end{array}$ & 0,0393 & 0,0447 & 0,3791 & $\begin{array}{c}120.31 \\
(0.0000)\end{array}$ \\
\hline Pepper & 0,1301 & 0,0656 & 0,0473 & $\begin{array}{c}12.81 \\
(0.0000)\end{array}$ & $-0,4250$ & 0,1310 & 0,0012 & $\begin{array}{c}5.78 \\
(0.0032)\end{array}$ \\
\hline $\begin{array}{c}\text { New } \\
\text { Potatoes }\end{array}$ & $-0,3984$ & 0,0860 & 0,0000 & $\begin{array}{c}14.92 \\
(0.0000)\end{array}$ & 0,0439 & 0,0980 & 0,6543 & $\begin{array}{c}2.33 \\
(0.0982)\end{array}$ \\
\hline Cucumber & 0,3823 & 0,0688 & 0,0000 & $\begin{array}{c}126.55 \\
(0.0000)\end{array}$ & $-0,0287$ & 0,1082 & 0,7911 & $\begin{array}{c}16.99 \\
(0.0000)\end{array}$ \\
\hline Peach & 0,0938 & 0,0567 & 0,0983 & $\begin{array}{c}1.51 \\
(0.2215)\end{array}$ & $-0,4540$ & 0,0819 & 0,0000 & $\begin{array}{c}15.67 \\
(0.0000)\end{array}$ \\
\hline Garlic & 0,1647 & 0,0485 & 0,0007 & $\begin{array}{c}6.55 \\
(0.0014)\end{array}$ & $-0,0003$ & 0,0987 & 0,9976 & $\begin{array}{c}2.42 \\
(0.0893)\end{array}$ \\
\hline All Products & 0,1824 & 0,0217 & 0,0000 & $\begin{array}{c}173.82 \\
(0.0000)\end{array}$ & $-0,1360$ & 0,0366 & 0,0002 & $\begin{array}{c}7.43 \\
(0.0005)\end{array}$ \\
\hline
\end{tabular}

Note: F statistic reported for the pool regression analysis, defined in Equation (3).

Table 2 - Estimates for parameter $\gamma$ from regression analysis, which is defined in Equation (3). Results for individual goods and whole dataset with all products.

\begin{tabular}{|c|c|c|c|c|c|c|}
\hline \multirow{2}{*}{ Distance } & \multicolumn{3}{|c|}{ Pre ICT } & \multicolumn{3}{c|}{ Post ICT } \\
\cline { 2 - 7 } & $\gamma$ & $\begin{array}{c}\text { Standard } \\
\text { Error }\end{array}$ & Prob. & $\gamma$ & $\begin{array}{c}\text { Standard } \\
\text { Error }\end{array}$ & Prob. \\
\hline Tomato & $-0,1167$ & 0,0130 & 0,0000 & $-0,2049$ & 0,0314 & 0,0000 \\
\hline Strawberries & 0,1079 & 0,0373 & 0,0040 & 0,1209 & 0,0311 & 0,0001 \\
\hline Apple & $-0,0424$ & 0,0134 & 0,0015 & $-0,1903$ & 0,0146 & 0,0000 \\
\hline Cucumber & $-0,2310$ & 0,0229 & 0,0000 & 0,1744 & 0,0353 & 0,0000 \\
\hline New Potatoes & $-0,1252$ & 0,0262 & 0,0000 & $-0,0476$ & 0,0286 & 0,0966 \\
\hline Pepper & $-0,0653$ & 0,0217 & 0,0027 & $-0,0306$ & 0,0427 & 0,4734 \\
\hline Peach & 0,0071 & 0,0188 & 0,7070 & $-0,0530$ & 0,0266 & 0,0467 \\
\hline Garlic & 0,0098 & 0,0160 & 0,5417 & 0,0620 & 0,0327 & 0,0581 \\
\hline \hline All Products & $-0,0729$ & 0,0072 & 0,0000 & $-0,0325$ & 0,0119 & 0,0062 \\
\hline
\end{tabular}

Note: Sample size pre ICT around 2200 daily price observations starting from $15^{\text {th }}$ of April 2010.

Sample size post ICT is around 900 daily price observations starting from $15^{\text {th }}$ of April 2011. Fstatistic related to Equation 3 estimate using pool regression analysis is reported in the previous table. 


\section{CONCLUSION AND POLICY RECOMMENDATIONS}

This paper has been prepared as a pilot study, but it has provided several interesting insights on the connection between ICTs and market performance. Within the central matter of the analysis lies the empirical evidence of market impact, which reveals that the level of market integration for most individual goods, as well as for aggregated market, has increased in the period after the introduction of the service. The increased integration was captured as decreased impact of the local demand onto the formation of the local market price. Transportation costs are proven to be significant factor in explaining price differences between different wholesale markets both in the period pre and post introduction of the service for all products, and for most estimates of markets for specific goods (excluding markets for peach and garlic in the period pre, and market for pepper in the period post introduction of the service), corroborating the need to control for transportation costs while testing the Law of One Price.

The major question is whether the service itself has truly influenced the level of market integration, or there were some other events in the market that had the impact on prices. Many professionals highlight the presence of considerable dumping of prices that is present in the market, but is not recognized nor sanctioned by the competent institutions in B\&H. Our methodology assumes that all the market imperfections exist throughout the period of study and are present in both pre and post ICT sample, so that there is no structural break in data due to these reasons. In addition, considering that the B\&H market is rather small, it is suggested that activities of large importers and other market participants could have reflected onto the equalization of prices. However, we do not have reason to believe that this activity existed only in period post ICT service either, so we assume that more movement of goods after ICT introduction could have occurred due to information on prices being readily available so that each agent could have acted in response to price signals.

We therefore find support to the argument that the impact of local demand onto the formation of the market price could have been reduced due to quantities supplied that have been adjusted by shifting goods towards markets with higher demand. The survey that we have conducted on service users as part of qualitative analysis on ICT service in agro-food market in $\mathrm{B} \& \mathrm{H}$, has indicated that majority of service users are small farmers for which transporting goods to different markets isn't profitable. Nevertheless, there exists significant portion of large producers and intermediary that have used the service, and at some point decided to shift their 
goods to a different market. In this regard, the question is not how many people have used the service, if those people that used could have had significant quantities of goods so that it could pay off for them to shift goods to a different market.

Although it might seem that improving market performance will only provide better gains to larger producers and middleman, the service has also proven to assist those that need the information most, including small producers that do not have reliable information about the true market prices when selling their goods at reduced prices, mostly to middleman. Although small users do not have sufficient quantities of goods that would make shipping goods to a different market profitable, they stated that the service has proved to be useful for them as well in providing them information. Our qualitative analysis therefore corroborated empirical findings suggesting that ICT introduction has improved information of agents in the market and therefore could have created impetus for larger market integration.

Considering that our qualitative findings ${ }^{2}$ have showed that better educated participants in the agro-food market that use the Internet tend to use the service, fighting a digital divide represents a crucial issue that the policy makers must further tackle in order to increase the ability of ICT to contribute towards curing of information asymmetry. Therefore, it would be required that service provider reaches out to wider populationandfarmersliving in distanced areas, and adjusting the service so that is easy to use, to enable those that are excluded to obtain relevant information. In addition, we suggest that farmers are informed that the provided service only reflects morning prices for the particular day, so that they do not think the prices reflect exact market prices at each point in time during the day, as it was proven the case so far. These observations suggest that having more frequent information on market, rather than opening market price, could have a significant influence on market performance. Further projects could be going in this direction to study impact of ICT on market performance when there is real time information on the prices in different locations.

While this study reveals that the level of agro-food market integration has increased after the introduction of the service, while our qualitative analysis suggested that there exist significant number of large producers and middleman that have shifted their goods onto different market to earn extra profits, it must be noted that there exists a need to broaden the study further to cover larger period of time. This is a pilot assessment that covered 16 months, andfor drawing

\footnotetext{
${ }^{2}$ Survey was done on 100 market participants who have used AgroLink service.
} 
conclusions with additional precision, hereby we suggest to expand the study to a longer period.

Given the fact that functioning of the markets have on the development of the country it would be necessary to explore the role that information provided can be used to tackle the market dis-functionalities and to catch irregular market practices by regulators using ICT.

\section{References and notes:}

Anderson, J. R. and Feder.G. (2007) Handbook of Agricultural Economics.Agricultural Extension. 3: 2343-2378.

Aker, J. C. (2008) Does Digital Divide or Provide? The Impact of Cell Phones on Grain Markets in Niger. Bureau for Research and Economic Analysis of Development (BREAD) Working Paper 177.

Agency for Statistics of B\&H (2011) Demography 2010. October 2011, Sarajevo

Agency for Statistics ofB\&H (2008a) Foreign Trade 2007.Thematic Bulletin 06. Sarajevo.

Agency for Statistics of B\&H. (2008b) Labour Force Survey 2008.Thematic Bulletin 10. Sarajevo.

Agency for StatisticsofB\&H (2008c) Persons in Paid Employment by Activity.November 2008. First Release Number 11. Sarajevo.

Bartlett W. (2008) Regional integration and free-trade agreements in the Balkans: opportunities, obstacles and policy issues, Available from: <http://www2.1se.ac.uk/europeanInstitute/research/LSEE/PDF\%20Files/Latest\%20Re search/2009item2bartlett.pdf $>$ [Accessed $1^{\text {st }}$ September 2012].

Bravo-Ortega C and D. Lederman. (2005) Agriculture and national welfare around the world: Causality and international heterogeneity since 1960. Policy Res. Work. Paper 3499. World Bank: Washington, D.C.

Brown, Jeffrey R., and AustanGoolsbee. (2002) Does the Internet Make Markets More Competitive? Evidence from the Life Insurance Industry. Journal of Political Economy, 110 (3), pp. 481-507.

Castells, M.(2002)The Internet Galaxy. Oxford University Press, Oxford.

Castells, M. (2010)The Rise of the Network Society, The InformationAge: Economy, Society and Culture, Vol 1.2nd ed.

Feder, Gershon\& Richard E.Just \& David Zilberman (1985) Adoption of Agricultural Innovations in Developing Countries: A Survey.Economic Development and Cultural Change, 33(2): 255-98.

Forum for Agricultural Research in Africa - FARA (2009).Inventory of Innovative Farmer Advisory Services using ICTs.

Foster, Andrew and Mark Rosenzweig (1995) Learning by Doing and Learning from Others: Human Capital and Technical Change in Agriculture.Journal of Political Economy. 103 (6): 1176-1209.

Gluschenko, K. (2003) Market integration in Russia during the transformation years, Economics of Transition, Vol. 11 No. 3, pp. 411-34. 
Gluschenko K., Karachevskaya D. (2010) Assessing a feasible degree of product market integration: a pilot analysis. Journal of Economic Studies Vol. 37 No 4, 2010, Emerald Group Publishing Limited

Heeks, R., 2002. Working Paper Series: Failure, Success and Improvisation of Information Systems Projects in Developing Countries, Manchester: University of Manchester, Precinct Centre, M13 9GH, UK.

Jensen, R. (2007) TheDigital Provide: Information (Technology), Market Performance, and Welfarein the South Indian Fisheries Sector. Quarterly Journal of Economics, 122(3): 879-924.

Ligon, E., SadouletE.(2007) Estimating the effects of aggregate agricultural growth on the distribution of expenditures. In Background Note for the World Development Report 2008. Washington, DC: World Bank.

Ministry of Foreign Trade and Economic Relations of B\&H (2009) Analysis of policies in the area of agriculture, nutrition and rural development of B\&H, Sarajevo

Smith, A. (1904) An Inquiry into the Nature and Causes of the Wealth of Nations, London: Methuen and Co., Ltd., ed. Edwin Cannan, Fifth edition.

Stigler, George J. (1961) The Economics of Information. Journal of Political Economy, 69(3): 213-25.

Stiglitz, Joseph E. (1989) Imperfect Information in the Product Market. In Handbook of IndustrialOrganization, Volume 1, ed. Richard Schmalensee and Robert D. Willig, 769-847. Amsterdam: Elsevier Science.

Stiglitz Joseph E. (2001) Information and the change in the paradigm in economics, Prize Lecture, by Columbia Business School, Columbia University, 1022 International Affairs Building, 420 West 118th Street, New York, NY 10027, USA.

World Bank, Agency for Statistics of B\&H, Statistic Institute of FB\&H, Statistic Institute of RS (2001), Living Standard Measurement Survey in Bosnia and Herzegovina, Sarajevo

World Bank. (2007a) World Development Report 2008: Agriculture for Development. Washington D.C.

World Bank. (2007b). Enterprise Activity, Labor Market Outcomes and Welfare: B\&H 2005-2006. Washington, DC.

World Bank (2010) Agricultural Sector Policy Note for Bosnia And Herzegovina: Trade and Integration Policy Note, Poverty Reduction and Economic Management Unit, Europe and Central Asia Region, Report No. 57919-BA 
Summary

\title{
The Impact of Agricultural Market Information System in Bosnia \& Herzegovina on Market Integration: Assymetric Information and Market Performance
}

\author{
Adisa Omerbegovic Arapovic \\ Sarajevo School of Science and Technology, Bosnia and Herzegovina

\section{Zana Karkin} \\ Sarajevo School of Science and Technology , Bosnia and Herzegovina
}

In a perfectly integrated market local demand has no impact on the formation of market price, since changes in local demand cause price equalization in the market through efficient allocation of resources (Pareto efficiency). Information is crucial to market performance and integration as market agents cannot explore arbitrage opportunities in its absence. This paper tests the impact of introduction of agricultural market information system (via SMS service which provides information on prices of agricultural items in different markets) on observed degree of market integration in agro-food market in Bosnia and Herzegovina $(\mathrm{B} \& \mathrm{H})$, pre and post the service. Degree of market integration is measured as the extent that local demand has on formation of prices in the market pre and post introduction of the Information and Communication Technology (ICT) service. The methodology assumed tests the Law of One Price, while taking into account transportation costs and concludes thatintroduction of the ICT service in agro-food market in Bosnia \&Herzegovina has increased the level of market integration. It is shown that the impact of the local demand onto formation of the local market price has decreased after the introduction of the ICT service. The results suggest that ICT may have a significant role in tackling information asymmetry and consequently promote market integration. This is a pilot assessment that covered only 16 months of daily price, so for the purpose of drawing conclusions with additional precision, it must be noted that there exists a need to broaden the study further to cover larger period of time.

Key words: Market integration, agriculture market in Bosnia and Herzegovina, Law of one price 